La Lepro 40, 4 (1971)

\title{
Inoculation Test with Human Leprous Material into the Testis of Mice Previously Injected with Sodium Iodine $\left({ }^{131} \mathbf{I}\right)$
}

\author{
KIYO SUSHIDA and NORIMASA HIRANO \\ (Department of Microbiology, Tokyo Women's Medical College)
}

The thyroid tissue becomes destroyed in the mice previously injected with sodium iodine $\left({ }^{131} \mathrm{I}\right)$, this destruction causes the body temperature to fall. Leprous bacilli were injected into the above treated mice and then the multiplication process of the bacilli were examined.

The mice were injected subcutaneously in the back with sodium iodine, $50 \mu \mathrm{c}$ per each animal. Approximately a month later human leprous material was injected. At this juncture the average body temperature of the mice was caused to fall about $1^{\circ} \mathrm{C}$ in contrast with the average body temperature of the control animals. It is generally recognized that the lowering of body temperature is related to the destruction of thyroid tissue. Into the testes of these mice human leprous material designated LL11, 21, 22, 23 were injected. This leprous material was emulsified and diluted. The number of bacilli injected were from 15,000 to 40,000 per one mouse. In this dilution, of course, small bacterial groups were found. The harvests of acid-fast bacilli in these testes were examined microscopically in every 16 months after the injection.

Retults: Up to 6 and 8 months after the injection of the leprous material into the testes of mice injected with sodium iodine, and the control animals (that is having no sodium iodine), acid-fast bacilli were found both scattered or gathered extracellularly $(+s)$; small groups of bacilli were sometimes found. Up to 10 and 16 months after injection into treated mice, the cells with acid-fast bacilli were found to be abundant, thus forming the socalled globi $(+G)$, which were found often in the capsel of the testis by the histological examination. The round form of globi were not found in this experiment, but the spindle forms of globi were observed. The acid-fast bacilli in the globi changed into segmented forms 16 months later.

From these results, tite can be inferred that the natural resistance of mice injected with sodium iodine is less than in the control mice. It was considered that resistance of the reticuloendothelial system (RES) had been diminished by the sodium iodine injection. 


\title{
放射性ヨウ化ナトリウム (131I) 注射マウス 精栄における人らい菌接種試験
}

\author{
須子田キ $\exists$ 平 野 憲 正 \\ （東京女子医科大学微生物学教室）
}

（受付 1971 年 9 月 8 日）

人らい菌の動物移植実験にあたつては感受性の高い動 物を選ぶと同時に，通常用いられている実験動物の感受 性を高め，また接種部についても同様に考慮されなけれ ばならない。以上の諸点についてはすでに多くの研究 が行なわれて来た。マウスは人らい菌に対しては決して 感受性の高い動物とはいえないが，扱いやすいという点 で多くの実験者はこれを用い，人らい菌に対する感受性 を高める目的で, 胸腺摘出, コルチゾン投与, あるいは X線照射など，単一に，あるいはこれらの処置を組合せ て人らい菌接種実験を行なつている1-7)。

$\mathrm{Rees}^{3)}$ は胸腺摘出マウスにさらにX線照射を行なつて 人らい菌を接種し, 相当良好な成績をあげている。接種 部については耳染を用いている。Shepard ${ }^{8)}$ はマウスの Foot-pad を用いて成功し, すでに広く応用実験への道 を展開している。Binford ${ }^{112)}$ は人らいが低体温部に発 生しやすいことから精巣内接種を行なつた。著者らもこ の考えに一致して人らい菌または鼠癩菌をウサギ，およ びマウスの精栄部に接種し，Tunica vaginalis によく

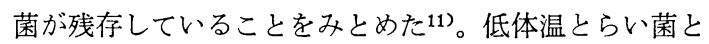
の関係は明かでないが，本実験においてはマウスの体温 を低下させ，かかるマウスに人らい菌接種を試みた。
その方法としてラットでは甲状腺摘出を行なうことが容 易であるが，マウスではこの手術はかなり侵襲が大きい ので放射性ヨウ化ナトリウム（ ${ }^{131} \mathrm{I} ）$ を注射し, 甲状腺 を破壊し, その機能低下の一つとして体温が低下する点 を応用し910)，このような処理を行なつたマウスを用い て人らい菌接種実験を行なつた。

\section{実験材料および方法}

使用菌株：らい患者結節は多摩全生園および復生病院 より分与されたもので10株を用いたが，本誌にはそのう ち LL11，21，22，および LL23の 4 株について述べ る。これらの材料は表 1 に示すようにいずれも治療中で ありまた再然患者が殆んどであつた。結節のスタンプ標 本中の菌数, その菌形, 接種菌数および飼育条件などを 記した。

131I 注射 : 体重 $18 \mathrm{~g}$ 前後の市販の dd 系雄マウスを用 いた。背部皮下に $50 \mu \mathrm{c} / 0.1 \mathrm{ml}$ ずつを注射した。実験初 期の考えでは放射線（ガンマ線）による侵襲をできるだ け少くする目的で LL11株を注射したマウスの一部につ いては $25 \mu \mathrm{c} / 0.1 \mathrm{ml}$ の量を用いた。なお ${ }^{131} \mathrm{I}$ 注射後, 約 1 カ月経ってから, らい菌接種を行なったので, その時

Table 1. Samples of LL-strains (lepromatous leprosy) and their qualities

\begin{tabular}{|c|c|c|c|c|c|c|}
\hline \multirow{2}{*}{ Strain } & \multicolumn{2}{|c|}{ Clinical finding* } & \multirow{2}{*}{$\begin{array}{l}\text { No. of bacilli } \\
\text { in a field** } \\
\text { (average) }\end{array}$} & \multirow{2}{*}{$\begin{array}{l}\text { Form of } \\
\text { organisms }\end{array}$} & \multirow{2}{*}{$\begin{array}{l}\text { No. of inoculated } \\
\text { bacilli into } \\
\text { a mouse }\end{array}$} & \multirow{2}{*}{$\begin{array}{l}\text { Condition } \\
\text { for the } \\
\text { breeding }\end{array}$} \\
\hline & Treatment & Recidive & & & & \\
\hline LL 11 & + & $?$ & $200 / \mathrm{F}$ & slender & $4 \times 10^{4}$ & $\begin{array}{l}\text { room } \\
\text { temperature }\end{array}$ \\
\hline LL 21 & + & + & $20 / \mathrm{F}$ & $\left\{\begin{array}{l}\text { solid \& } \\
\text { segmented }\end{array}\right.$ & $4 \times 10^{4}$ & $20 \pm 1^{\circ} \mathrm{C}$ \\
\hline LL 22 & + & + & $30 / \mathrm{F}$ & do & $1.5 \times 10^{4}$ & $50-55 \%$ \\
\hline LL 23 & + & + & $200 / \mathrm{F}$ & segmented & $3 \times 10^{4}$ & humidity \\
\hline
\end{tabular}

* Clinical findings of the patient, from which leproma obtained.

** Acid-fast bacilli in a stamp-smear sample from a leproma of the human leprosy. 
点における被検マウス体内のガンマ線の測定をシンチレ ーションカウンターにて計測し，マウス体内で菌が直接 影響をうける放射量を参考として記録した。

${ }^{131}$ I 注射マウスの体温測定： 131I を注射したマウスに おける甲状腺は組織学的には正常の濾胞はほとんど破壊 され，間質の増生，細胞の浸潤があり，体温測定はかか る状態のマウスについて行なわれた。甲状腺の機能は環 境温度によって影響をうけるといわれている99ので，動 物飼育室の温度並びに湿度についても記録し，体温との 関係について検討した。しかし常温で飼育を続けたのは LL11株接種実験だけで，その後の菌株接種の実験はす べて $20 \pm 1^{\circ} \mathrm{C}, 50 \sim 55 \%$ 湿度の恒温室で 飼育された。体 温の測定法は，LL11株接種実験群の中から注射群と対 照群から，それぞれ10匹ずっをとり，これらのマウスに ついて測定を続けた。 サーミスタエレメント（マウス用） を用い，肛門にて，毎月 1 回，午後 $2 \sim 4$ 時までに測定 し，10匹の平均值をもつて対照群と比較した。

人らい菌のマウス精巣接種 : 131 I を注射したあと, 約 1 カ月目のマウスに人らい菌の接種を行なつた。らい結 節は皮膚を除き，腫瘤部を細砕し，生理食塩水を少量加 えて乳剂とし，粗組織片は滅菌綿にて漉した。濾液中の 菌数は $0.1 \mathrm{ml}$ 中約 $1.5 \sim 4 \times 10^{4}$ 個であつて, 1 側の 精巣内に $0.1 \mathrm{ml}$ 接種した。接種菌数は各菌株によって 異り，表 1 に記した。接種菌量については，もし正確に 精巣内のみに注射するならば $0.02 \sim 0.03 \mathrm{ml}$ である。し たがつて $0.1 \mathrm{ml}$ の量は余分の液が精紧周辺に注射され たものと思われる。このように精巣内のみにあえて限定 しなかつたのは，先の実験で，精巣被膜下に小結節を みたことがしばしばあった経験にもとづくもので，精巣 のどの部分がらい菌の感染，増殖に摘しているか未だ不 明であったからである。対照としては，LL11株では 25 $\mu \mathrm{c}$ 注射群を, LL21，LL22，LL23株については 無処 置 $(0 \mu \mathrm{c})$ 群についても実験した。死菌については材料 の不足から実験できなかった。

人らい菌接種マウスは月を逐って屠殺し，検查を行な ったが，その間死亡したものについても検査した。肉眼 的変化を観察したあと，接種部および反対側の精巣，局 所リンパ節，肝，脾の断面をそれぞれスライドグラスの 上にスタンプし，1夜室温にて乾燥したあと，火焰固定 を行ない，Ziehl-Neelson 法にて染色，全視野を鏡検し， 抗酸菌の有無，殊に細胞との関倸を観察した。接種部に おいて肉眼的変化を認めたものについては，一部はホル マリン固定し, 病理組織学的検査を行なった。組織標本 の染色法はへマトキシリンイオジン $(\mathrm{HE})$ 染色，抗酸菌
染色，マツソン変法による染色を行なった。甲状腺の破 壊の程度を知るために一部のものについてはその病理組 織標本を作り検討した。

\section{実験成紸}

マウスの体温について

1311 $50 \mu \mathrm{c}$ および $25 \mu \mathrm{c}$ 注射群と, 無処置対照群にマウ スの各々10匹ずつの平均体温を表 2 に示した。 ${ }^{131}$ I 注射 後 3 週目まではアイソトープ貯蔵室前室にて飼育したの で, そこで測定した。人らい菌接種と同時に常温の動物 室に移し，6力月間測定した。131I 注射マウスの平均体 温は対照群マウスに比べて一般に体温の低下を示すが， その差は $0.2 \sim 1.0^{\circ} \mathrm{C}$ で, 平均体温の差は一定でなく, また，個々のマウスの体温にも差異が認められた。時に は対照群マウスのあるものは ${ }^{131}$ I 注射群より低いもの もあった。 $50 \mu \mathrm{c}$ と $25 \mu \mathrm{c}$ 注射では $50 \mu \mathrm{c}$ 注射群の方が僅 かではあるが平均体温は低く，この成績は甲状腺の破壊

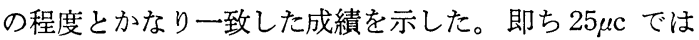
甲状腺内にしばしば正常濾胞の残存する組織像が認めら れた。 6 力月間, 6 回の側定值について, $50 \mu \mathrm{c}$ 注射群 マウスの平均体温は $0.66^{\circ} \mathrm{C}, 25 \mu \mathrm{c}$ 群では $0.5^{\circ} \mathrm{C}$, 対照 群の平均体温より低くかった。本実験においては個々の

Table 2. Temperature of mice injected with ${ }^{131} \mathrm{I}$

\begin{tabular}{|c|c|c|c|c|c|}
\hline \multirow{2}{*}{$\begin{array}{l}\text { Month } \\
\text { after } \\
\text { injection } \\
\text { with 131I }\end{array}$} & \multicolumn{3}{|c|}{$\begin{array}{l}\text { Average } \\
\text { temperature } \\
\text { on the } 10 \text { mice }\end{array}$} & \multirow{2}{*}{$\begin{array}{l}\text { Environmental } \\
\text { temperature } \\
\& \text { humidity }\end{array}$} & \multirow[t]{2}{*}{ Month } \\
\hline & $50 \mu \mathrm{c}$ & $25 \mu \mathrm{c}$ & 0 & & \\
\hline 1 (week) & 38.7 & 38.9 & 37.6 & $20^{\circ} \mathrm{C} \& 90 \%$ & June \\
\hline 3 (week) & 38.1 & 38.4 & 38.9 & $20^{\circ} \mathrm{C} / 195 \%$ & June \\
\hline 1 month & 38.2 & 38.5 & 38.9 & $31^{\circ} \mathrm{C} / 164 \%$ & July \\
\hline $3 \prime \prime$ & 36.2 & 36.4 & 37.2 & $22^{\circ} \mathrm{C} / 155 \%$ & Sep. \\
\hline $5 \prime \prime$ & 36.8 & 37.0 & 37.5 & $20^{\circ} \mathrm{C} / 70 \%$ & Nov. \\
\hline $6 \prime \prime$ & 37.0 & 37.1 & 37.8 & $22^{\circ} \mathrm{C} / 134 \%$ & Dec. \\
\hline
\end{tabular}

マウスの体温低下と，人らい菌接種成績との比較を行な っていないが，後に述べる ${ }^{131}$ 注射群において 細胞内 抗酸菌陽性のものがしばしば認められた成績とこの平均 体温の低下とは一致する現象であると思う。個々のマウ スの体温との関倸についてはさらに実験中である。

室温と湿度

LL11株接種実験の行われた 常温の動物室は最低 $20^{\circ}$ $\mathrm{C}$, 最高 $32^{\circ} \mathrm{C}$ ，湿度は $30 \sim 100 \%$ の開きがあつた。LL21， LL 22，および LL 23株を用いた実験は先に述べた如く 恒温室で行なわれた。 
Table 3. Doses of gamma-rays in mice injected with ${ }^{131} \mathrm{I}$ after 1 month

\begin{tabular}{l|r|r|r}
\hline \multirow{2}{*}{ Organ } & \multicolumn{3}{|c}{$\mathrm{CPM} / 10 \mathrm{mg}$ of organ } \\
\cline { 2 - 4 } & \multicolumn{1}{c|}{$50 \mu \mathrm{c}$} & $25 \mu \mathrm{c}$ & $25 \mu \mathrm{c}$ \\
\hline Lung & 383.5 & 172.7 & 44.4 \\
Heart & 446.8 & 351.8 & 94.4 \\
Liver & 46.6 & 17.2 & 9.0 \\
Spleen & 1191.5 & 24.7 & 3.0 \\
Kidny & 602.8 & 110.3 & 41.0 \\
Lymph-node & 959.5 & 1290.6 & 368.7 \\
Skin & 353.9 & 96.5 & 17.5 \\
Thyroid & 7335.0 & 5184.0 & 40519.0 \\
Testis & 474.5 & 47.6 & 4.4 \\
\hline
\end{tabular}

Back-ground (1023.2)

\section{マウス体内放射線量（ガンマ線）}

人らい菌接種の行なわれた時期, 即ち ${ }^{131}$ I 注射後約 1 カ月目のマウス体内臓器の放射線量を表 3 に示した。 接種部精单を初めとし, 甲状腺, その他の各臓器につい ては10mg 中の放射線量 (CMP) をもって比較した。表 には $50 \mu \mathrm{c}$ 注射マウスと $25 \mu \mathrm{c}$ 注射マウスについて示した が，数值では両者に著明な差はなかつた。CMP 值はバ ックグラウンド值を差引いたもので， $50 \mu \mathrm{c}$ 注射マウス の甲状腺は7335 CMP，脾は1191.5，リンパ節は 959.5 と残存しており，25 2 c では甲状腺 5184 , 脾 40519, リ ンパ節2438 CMP で, 接種部の精巣では殆んど 僅かで あって，接種菌に放射線が直接影響を及ぼすことは考え られない。

\section{人らい菌接種成績}

表 4 は人らい菌 LL 11株，LL 21株，LL 22株および LL 23株をマウスの精巣内に接種した成績を示した。人 らい菌接種後 6 力月位までは散在性の, ときには小菌塊 の抗酸菌がみとめられたが，このような所見は ${ }^{131} \mathrm{I}$ 注 射マウスのみならず，非注射の対照マウスにおいてもし ばしば認められるもので，人らい菌の残存か，あるいは 正常マウスに認められる抗酸菌かはその区別は困難であ る。それ故菌接種後 9 力月頃からの成績を取上げた。

LL11株接種成績は，接種後 $10 ， 11 ， 13 ， 14 ， 15$ およ び16カ月目のそれぞれ接種部の精巣から細胞内に抗酸菌 がみとめられた。これらのマウスは ${ }^{131} 50 \mu \mathrm{c}$ ，あるい は25 $\mu \mathrm{c}$ 注射されたものである。抗酸菌の検索は組織断 面のスタンプ標本によるもので, 宿主細胞と菌との関係 が観察された。したがって菌の増殖を定量的に示すもの
Table 4. Inoculation with human leprous bacilli in testes of mice injected with ${ }^{131} \mathrm{I}$

\begin{tabular}{|c|c|c|c|c|c|c|c|c|}
\hline \multirow{3}{*}{$\begin{array}{l}\text { Months } \\
\text { after } \\
\text { inocula- } \\
\text { tion with } \\
\text { bacilli }\end{array}$} & \multicolumn{8}{|c|}{ Acid-fast bacilli in testes } \\
\hline & \multicolumn{2}{|c|}{ LL 11} & \multicolumn{2}{|c|}{ LL 21} & \multicolumn{2}{|c|}{ LL 22} & \multicolumn{2}{|c|}{ LL 23} \\
\hline & $50 \mu \mathrm{c}$ & $25 \mu \mathrm{c}$ & $50 \mu \mathrm{c}$ & 0 & $50 \mu \mathrm{c}$ & 0 & $50 \mu \mathrm{c}$ & 0 \\
\hline 8 & & & $H s$ & - & - & - & $+\mathrm{s}$ & $+\mathrm{s}$ \\
\hline 9 & & / & $H s$ & $+s$ & - & - & $+s$ & - \\
\hline 10 & ／ & $+\mathrm{G}$ & $+\mathrm{G}^{*}$ & - & $+\mathrm{G}$ & - & - & - \\
\hline 11 & $+\mathrm{G}$ & ～ & $+\mathrm{G}$ & - & - & - & - & - \\
\hline 12 & - & l & $+\mathrm{G}$ & - & / & / & l & / \\
\hline 13 & $+\mathrm{G}$ & / & - & - & / & / & ／ & 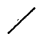 \\
\hline 14 & ／ & $+\mathrm{G}$ & $+s$ & - & - & $+s$ & $+\mathrm{G}$ & - \\
\hline 15 & I & $+G^{* *}$ & I & I & $+\mathrm{G}$ & $+s$ & - & - \\
\hline 16 & $/$ & $+\mathrm{G}$ & / & I & - & - & - & - \\
\hline
\end{tabular}

$+\mathrm{G} \cdots \mathrm{Globi}$, less than 10 in whole fields of stamp-smears.

+s $\cdots$ scattered acid-fast bacilli less than 100 in whole fields.

Hs $\cdots$...do, more than 100 bacilli.

*... found in inguinal lymphnode.

$* * \ldots$ also found in spleen.

ではないが，対照との比較をあらわす意味で全視野にお ける抗酸菌数を散在性のものと, 細胞内のものとに分け て示した。散在性のものは油浸レンズで 1 視野に数個み とめられるものを+ S, 散在性で時としては菌塊を示す もので全視野に100コ以上のものをHsとした。これらは いずれも細胞外に菌の存在するもので, 散在性の菌の他 に細胞内に抗酸菌を含有するもので，いわゆる globi と思われるものが全視野に数個認められるものを+Gと した。以上の成績は殆んど接種部の精巣における所見で あるが，LL11株の15カ月目 マウスの 1 匹からは接種部 の精巣のみならず脾にも細胞内抗酸菌を認めた。

病理組織標本は，10 力月目 (LL11-10 M)，11力月 目 $(\mathrm{LL} 11-11 \mathrm{M}) ， 13$ 力目 $(\mathrm{LL} 11-13 \mathrm{M})$ ，および14 カ月目 (LL11-14M) について作製した。いずれも接 種局所に変化がみとめられ，その部分，殊に精巣被膜あ るいは被膜直下に多数の抗酸菌が証明された。

LL21株接種試験では，50 $\mathrm{cc}$ 注射 マウス群は菌接種 後, 8 力月以後, 14力月まで抗酸菌が認められたが, $10,11,12$ 月目のスタンプ標本中にはいずれも globi が証明された。このうち10カ月目のものでは局所リンパ 節にも globi が認められた。また10，11，12力月目の細 胞内抗酸菌はその数が少なく, いわゆる抗酸菌の充満し 
たglobi とは言い難い。

LL22株では10および15力月目に，LL23株では14カ月 目のみに globe が認められた。

対照群マウスでも時としては散在性抗酸菌がな扔 15 力 月目までも認めるものがあつたが菌数は少なく，いずれ も細胞外に存在した。

2 代目継代接種の試み

LL11株接種実験の結果，globi が認められた，接種 後10力月目，13力月目，14力月，16力月目のマウスにお いてはそれぞれ精巣の一部を乳戍として数匹のマウスに 継代移植を試みた。先に述べたように精巣の一部を病理 標本作製に用いたのこりであり，その乳剤中の抗酸菌は 1 白金耳中に殆んぞ認められない位の材料であつたが， 試みに数匹のマウスの精巣内に注射した。これら継代用 被検マウスは予め50 $\mu \mathrm{c}$ の ${ }^{131}$ 在注射されたものもあっ たが，非注射 $(0 \mu \mathrm{c})$ のものもあった。それぞれ 9 力月 以上の成績を表 5 にまとめた。成績の得られた 22 匹のマ

Table 5. Experimental results to 2nd transfer from infected mice with humen leprous bacilli

\begin{tabular}{|c|c|c|c|c|c|c|}
\hline \multirow[b]{2}{*}{ Strain } & \multicolumn{3}{|c|}{ 1st infection } & \multicolumn{3}{|c|}{ 2nd transfer } \\
\hline & $\begin{array}{l}131 \mathrm{I} \\
(\mu \mathrm{c})\end{array}$ & Month & $\begin{array}{l}\text { Acid- } \\
\text { fast } \\
\text { bacilli }\end{array}$ & $\begin{array}{l}131 \mathrm{I} \\
(\mu \mathrm{c})\end{array}$ & Month & $\begin{array}{l}\text { Acid- } \\
\text { fast } \\
\text { bacilli }\end{array}$ \\
\hline \multirow{4}{*}{ LL 11} & 25 & 10 & $+\mathrm{G}$ & 50 & $\begin{array}{r}9 \\
10 \\
11 \\
12\end{array}$ & $\begin{array}{c}- \\
\overline{-} \\
+\bar{G}^{*}\end{array}$ \\
\hline & 50 & 13 & $+\mathrm{G}$ & 50 & $\begin{array}{r}9 \\
11 \\
12 \\
14\end{array}$ & $\begin{array}{l}- \\
\overline{-} \\
-\end{array}$ \\
\hline & 25 & 14 & $+\mathrm{G}$ & 0 & $\begin{array}{l}10 \\
11 \\
13\end{array}$ & $\begin{array}{l}- \\
-\end{array}$ \\
\hline & 25 & 16 & $+\mathrm{G}$ & $\begin{array}{r}50 \\
0 \\
0\end{array}$ & $\begin{array}{r}9 \\
9 \\
10\end{array}$ & $\begin{array}{l}+s \\
\frac{1}{+s}\end{array}$ \\
\hline LL 21 & 50 & 10 & $+\mathrm{G}^{* *}$ & 0 & $\begin{array}{l}10 \\
11 \\
12 \\
13 \\
14 \\
15\end{array}$ & $\begin{array}{l}\overline{-} \\
+\mathrm{s} \\
\overline{-} \\
\overline{+s}\end{array}$ \\
\hline LL 23 & 50 & 14 & $+\mathrm{G}$ & 50 & $\begin{array}{r}9 \\
10 \\
11\end{array}$ & $\begin{array}{l}\overline{-} \\
-\end{array}$ \\
\hline
\end{tabular}

* ....Acid-fast bacilli found in the testes, and also in spleen.

**... Acid-fast bacilli found in the lymphnode.
ウスのうち 5 匹に抗酸菌が認められたがそのうち 1 匹, LL 11 株接種の 2 代目，12力月目のマウスでは，接種部 および反対側の精巣とその脾に多数の抗酸菌が, globi と共に検出された。他の 4 匹は散在性，小菌塊を示寸程 度に抗酸菌が検出されたものであつた。

本実験で証明された globi は鼠䫐菌における如く，抗 酸菌が充満して, globi が円形を示すものは殆んど認め られず，その形は紡鍾形をなし (Fig. 3)，その核の両 端に抗酸菌が充満しているもので，大部分は組織球と思 われる。

\section{病理組織学的検查}

LL11－10M，LL 11 株接種後 10力月目に屠殺したマ ウスの病理組織学的所見である。精巣全体は萎縮し，被 膜の肥厚が著明である。細精管は全体としてはその構造 を保ち, 被膜直下の細精管は一部破壊され, 上皮の混濁” 腫脹，一部石灰沈着がみとめられた。実質部間質には 所どころ組織球性細胞と, 形質細胞, リンパ球, 纎維芽 細胞の増生が認められ，所どころに顆粒状の抗酸菌がみ とめられた。被膜直下および間質には抗酸顆粒の大喰球 の浸潤が著明であつた。一部血色素の沈著もみとめられ た（Fig. 4，5，6)。抗酸菌は被膜の特にその一部に多 数認められ (Fig. 10), 間質, 細精管に少数証明され た。このマウスは予め ${ }^{131} 25 \mu \mathrm{c}$ を注射されたもので あって，その甲状腺は全体萎縮し，殊に滤胞の萎縮が強 く, 殆んど正常構造（Fig. 1) を保つものはなく，コロ イドも認为られず全般に繊維化していた。形質細胞，リ ンパ球の浸潤は中等度であった。滤胞の上皮細胞は膨 化, 変性, 混濁, 腫镺し, 一部抗酸顆粒細胞がみとめら れた (Fig. 2)。

LL11-11M，同じく11 カ月目に屠殺されたマウス で，131I は予め50 $\mu \mathrm{c}$ 注射されたものである。精巣被膜 は10Mマウスに比して, 軽度に肥厚しているが変化は少 なく，実質，間質にも殆んど変化は認められなかった が，接種部と思われる被膜直下に，細胞浸潤があり，組 織球，および抗酸菌が認められた(Fig. 7，8，9，11)。

LL11-13M， 131I 50 $\mu \mathrm{c}$ を予为注射され，人らい菌接 種後，13力月目屠殺されたマウスである。精巣被膜は軽 度に肥厚, 被膜下に少数の細胞浸潤が認められるが抗酸 菌は認められなかった。被膜下および間質に抗酸顆粒細 胞がみとめられた。

\section{考 案}

低体温部であるという点から人らい菌接種部位として 注目されていた精巣部接種実験について，著者らは先に 
マウスおよびウサギを用いて精巣部に人らい菌の接種を 行ったな。その結果は Tunica vaginalisに抗酸菌を含む 小結節を認めた ${ }^{11)}$ 。これは Binford ${ }^{122}$ の成績とも一致す るが，継代によって消失した。本実験は接種マウスの体 温を予为低下させておいて，その精巣に人らい菌接種を 行ない, 接種された抗酸菌の動態を追求した。体温低下の 目的で放射性ヨウ化ナトリウムをマウスに注射したが， その理由は ${ }^{131} \mathrm{I}$ により甲状腺は破壊され, Thyroxine の分泌抑制が起る。組織所見でも正常の濾胞は破壊され ていることが確認されたが， Iodine のアミノ酸結合お よびそれらの重合の阻害作用によることが考えられる。 その結果低ヨード, Thyro-globulin の減少により, 代 謝障害が起り, その一症候として体温の低下が起る。体 温の低下が直接らい菌の感染に影響があるかどうかは不 明であるが，体温の低下を示す時期の ${ }^{131}$ を注射され たマウスの E. coli に対する低抗性は明らかに抑制さ れることを報告した。甲状腺ホルモンの分泌と感染との 関係については Gutierrez ${ }^{13)}$ は L-triiodothyroxine $\left(\mathrm{T}_{3}\right)$ は感染に対する抵抗性を增すと報告し，その中に Lurie et al. は thyroid hormon はラビットの結核感染に対す る自然抵抗性を増し，甲状腺摘出を行なえば逆の影響が あると述べている。 thyroid hormon の鼠癭菌感染に 対しては Koh et al. ${ }^{14)}$ はマウスの抵抗性は $\mathrm{T}_{4}$, 殊に $\mathrm{T}_{3}$ によって増大されると報告しているが ${ }^{131} \mathrm{I}$ によっては 特に逆の成績を示していない。本実験では ${ }^{131} \mathrm{I}$ 注射さ れたマウスにおいては非注射群マウスに比べて抗酸菌を 認める例が多いばかりでなく, 菌接種後大凡 9 力月以後 になると細胞内に抗酸菌の充満している所見が認められ ることで，このことは ${ }^{131} I$ 注射により明らかにマウス の人らい菌に対する自然抵抗性が下っていることを証明 している。

継代成績については一部の材料について行なった試験

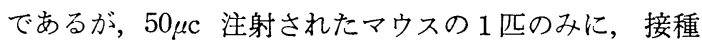
部のみならず内臟にまで抗酸菌が及んでいる所見が得ら れたが，3代目継代実験では ${ }^{131}$ を注射されていない マウスに移植した結果は陰性であった。

人らい菌のマウスーの動物移植については未だ将来の 問題であるが，免疫学的立場からマウスの自然抵抗性を 下げる一つの手段として ${ }^{131}$ I 注射マウスを用いること は検討されてよいことと思う。抗リンパ球血清その他の 免疫抑制剂の応用》が当然考えられるが，実際問題とし て長期にわたる人らい菌の動物移植実験においてはなお 種々の点が問題となり取り入れる事に困難を覚える。実 験動物への侵襲が少なく，しかも長期に持続的に抵抗性
を下げる方法が期待される。131I の注射量，回数，さら にマウスの体温を指標として被検マウスを選び出し，こ れに人らい菌移植実験ができるかどうか等について目下 研究を続けている。

\section{結論}

放射性ヨウ化ナトリウム（131I）をマウスに注射する と，その平均体温㧍よび，網内系機能の低下を示す。か かるマウスの精巣内に人らい菌接種を行なった。その結 果, 対照の無処置マウス群に比べて抗酸菌を検出するも のが多く，またしばしば細胞内に充満する抗酸菌 (globi) をみとめるものがあった。

終わりに放射性物質注射マウスの飼育, 監理について 便宜を御与え下さいました東京女子医科大学生化学教 室, 松村義宽教授に感謝し, 病理組織標本作製に当って 御援助下さいました同学病理学教室今井三喜教授に感謝 致します。また病理組織所見に対する御指導, 御意見を 賜わりました日本医科大学病理学教室福士勝成教授に心 から感謝申し上げます。

\section{文献}

1) C. H. Binford: Comprehensive program for inoculation of human leprosy into laboratory animals, Publ. Hlth. Rep., 71 : 995(1956).

2) C. C. Shepard, et al.: Mycobacterium leprae in mice: minimal infections dose, relationship between staining quality and infectivety, and effect cortisone, J. Bact., $89: 365$ (1965).

3) J. W. R. Rees: Enhanced susceptibility of thymectomized and irradiated mice to infection with mycobacterium leprae, Nature, $211: 657$ (1966).

4) J. M. Gaugas : Effect of X-irradiation and thymectomy on the development of mycobacterium leprae infection in mice, Brit. J. Exp. Path., $48: 417$ (1967).

5) C. C. Shepard et al.: Increased growth of mycobacterium leprae in thymectomyzed-irradiated mice after foot-pad inoculation, Int. J. Lep., $36: 224$ (1968).

6) J. W. R. Rees : Recent advanced in the transmission of human leprosy to mice, Int. J. Lep., $36: 584$ (1968).

7) J. M. Gaugas : Enhancing effect of antilymphocytic globulin on human leprosy infection in thymectomized mice, Nature, 220 : 1246 (1968).

8) C. C. Shepard: Acid-fast bacilli in nasal excretions in leprosy and results of inoculation of mice, Am. J. Hyg., 71 : 147 (1960). 
9) A. A. H. Kassenaar, et al.: The effect of environmental temperature on the blood protein bound iodine content of thyroxine maintained thyroidectomized rats, Acta Endocrinologica, $21: 37$ (1956).

10) T. Kamei, et al. : Sex difference in the renal retention of thyroxine in mice, Endocrinology, $77: 879(1965)$.

11）平野憲正, 須子田キョ：㿎のウサギ副辠丸内接 種, レプラ, $30: 200$ (1961).

12) C. H. Binford: Transmission of mycobacterium leprae to animals, nerve involvement in ear of hamster, Int. J. Lep., 33: 865 (1965).

13) R. Gutierrez: Preliminary report on the effects of L-triiodotyronine, radioactive Iodine ${ }^{131}$, and methimazole on experimental murine leprosy, Lep. Rev., 38 : 31 (1966).

14) K. J. Koh, et al.: The influence of thyroid and antithyroid substances on murine leprosy, 1. Comparison of host-parasite relationship within liver lesions, Int. J. Lep., $37: 147$ (1969).

\section{Explanation of photographs}

Fig. 1. Thyroid tissue of normanl mouse. H.E. $\times 100$

Fig. 2. Thyroid tissue after injection with ${ }^{131} 25 \mu$ into the mouse. H.E. $\times 100$

Fig. 3. Globi found in a stamp-smear of testis of the mouse (LL11-10M). Ziel-Neelsen' staining, $\times 1000$

Fig. 4. Testis of the mouse (LL11-10M). H.E. $\times 35$

Fig. 5. Testis of the mouse (LL11-10M), H.E. $\times 100$

Fig. 6. Testis of the mouse (LL11-10M). H.E. $\times 420$

Fig. 7. Testis of the mouse (LL11-11M). H.E. $\times 35$

Fig. 8. Testis of the mouse (LL11-11M). H.E. $\times 100$

Fig. 9. Testis of the mouse (LL11-11M), H.E. $\times 420$

Fig. 10. Acid-fast bacilli in capsular tissue of testis (LL11-10M). Ziehl-Neelsen' staining, $\times 1000$

Fig. 11. Acid-fast bacilli in the subcapsular tissue of testis (LL11-11M). Ziehl-Neelsen' staining, $\times 1000$ 

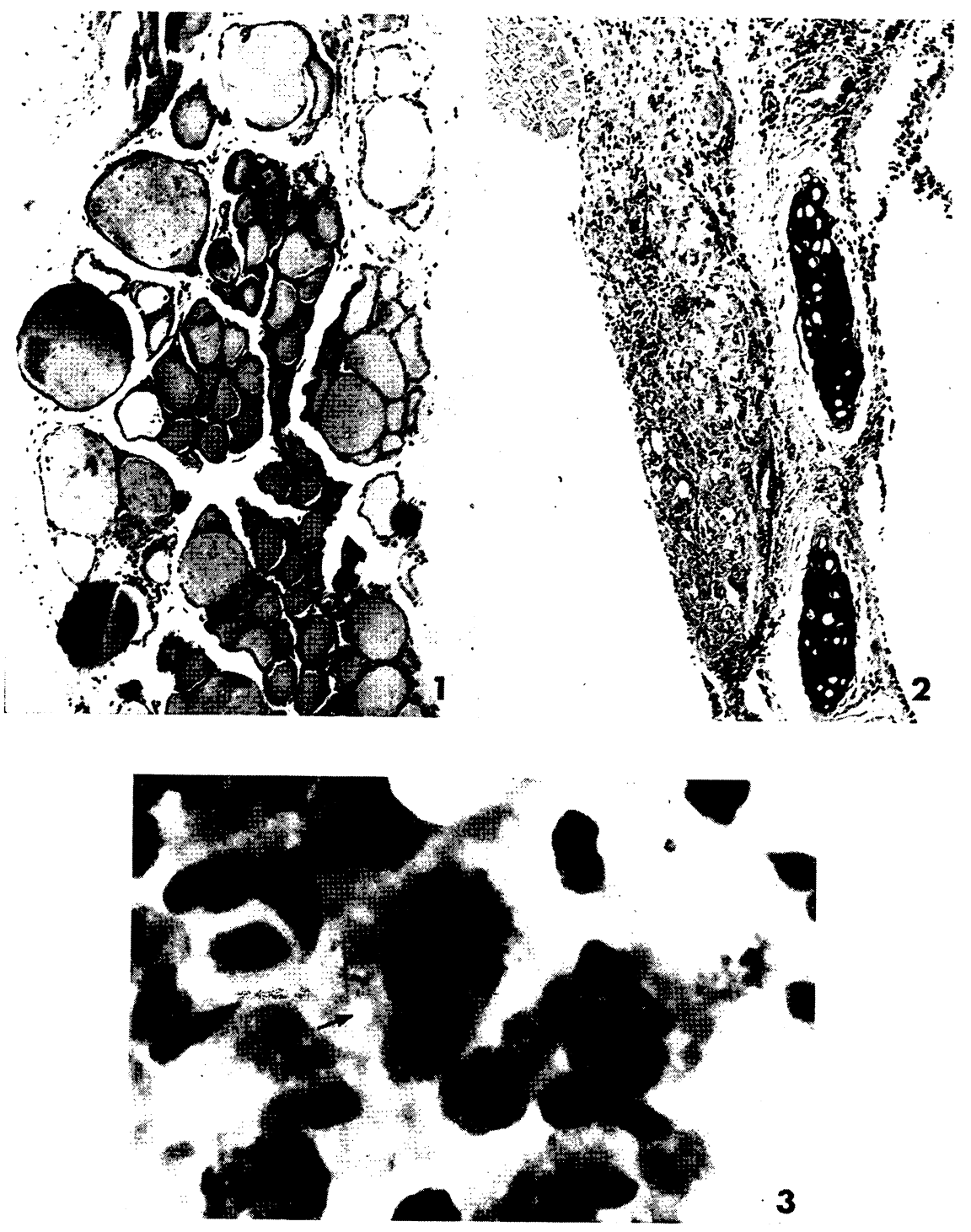


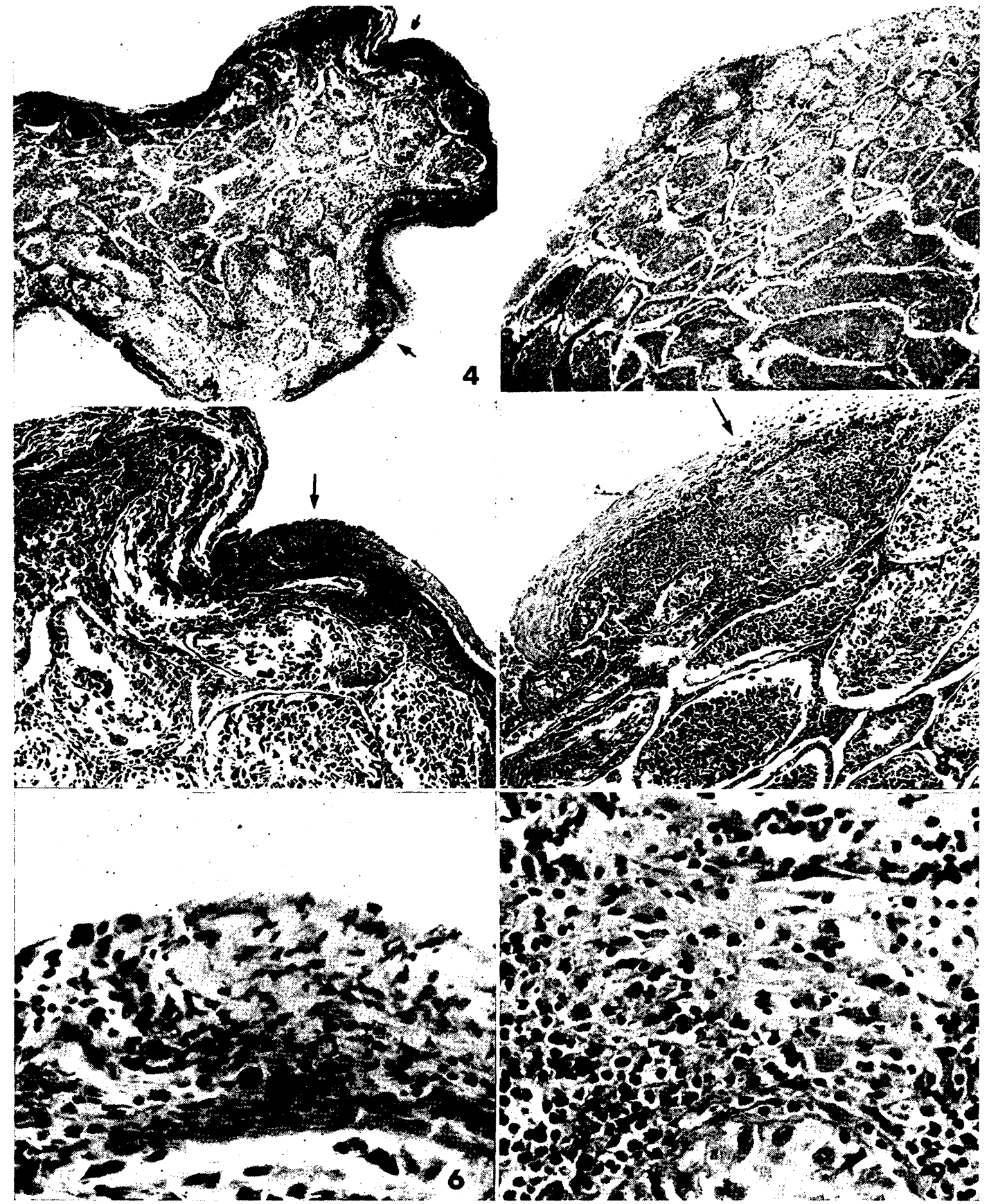




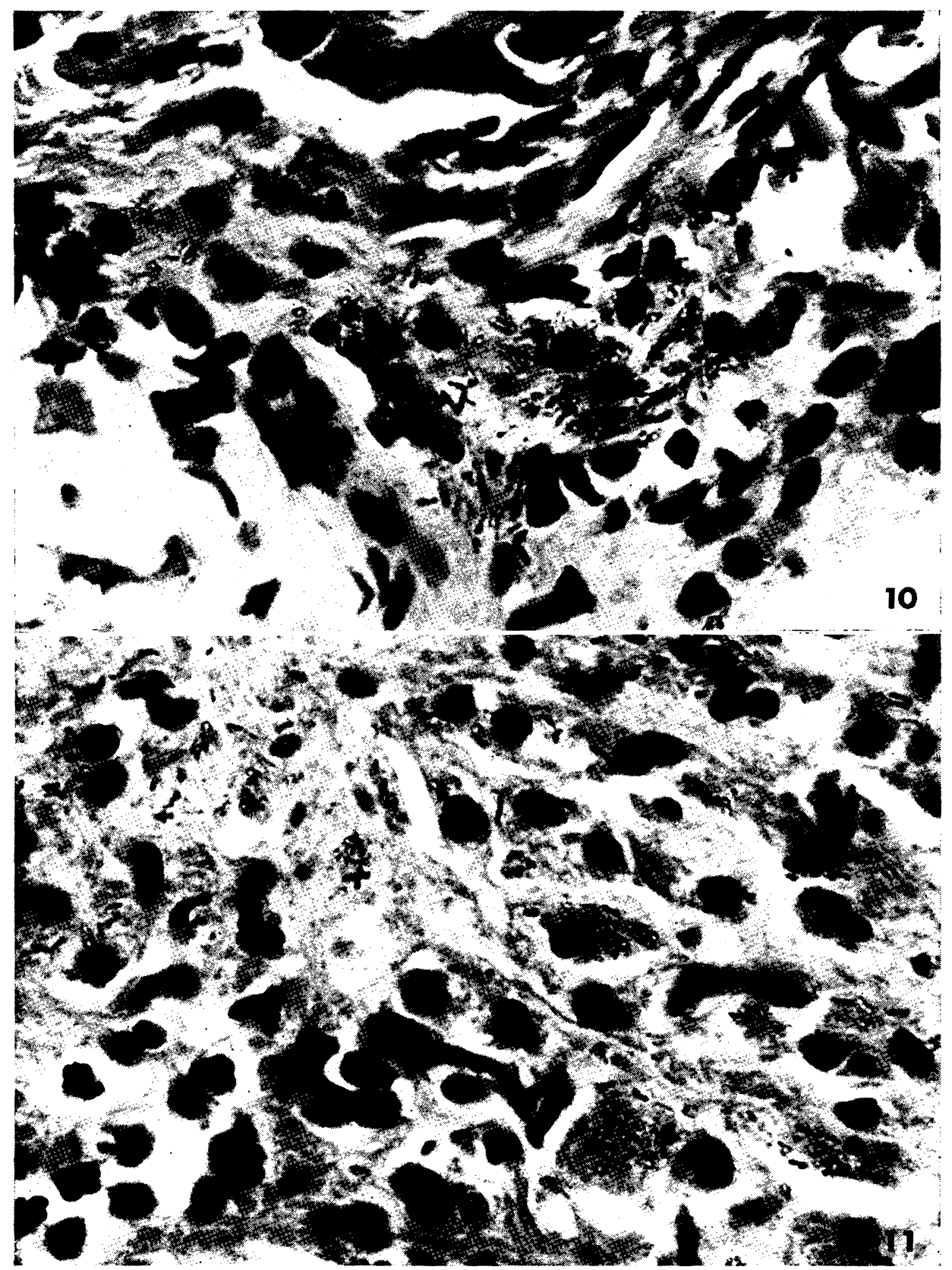

